\title{
Analisis Work-Life Balance para Karyawan Bank BJB Cabang Indramayu
}

\author{
Banatun Nafis ${ }^{1}$, Arianis Chan ${ }^{2}$, Sam'un Jaja Raharja ${ }^{3}$ \\ ${ }^{1}$ Departemen Administrasi Bisnis, Universitas Padjadjaran, E mail : bntnafis21@gmail.com \\ ${ }^{2}$ Departemen Administrasi Bisnis, Universitas Padjadjaran, E mail : arianis.chan@unpad.ac.id \\ 32Departemen Administrasi Bisnis, Universitas Padjadjaran, E mail : s.raharja2017@unpad.ac.id
}

\begin{abstract}
Abstrak
Penelitian ini bertujuan untuk mengetahui dan menganalisis Work-Life Balance para karyawan Bank BJB Cabang Indramayu. Dimensi penting dalam Work-life Balance adalah Work Interference with Personal Life, Personal Life Interfence with Work, Personal Life Enhancement of Work dan Work Enchancement of Personal Life. Metode Penelitian yang digunakan dalam penelitian ini adalah metode kualitatif-deskriptif. Penelitian ini menganalisis dan menggambarkan keadaan Work-Life Balance para karyawan Bank BJB Cabang Indramayu. Data yang diperoleh untuk penelitian ini didapatkan dari wawancara dengan pihak terkait dan studi dokumentasi. Hasil dari penelitian ini menunjukan bahwa karyawan Bank BJB Cabang Indramayu telah memiliki empat dimensi Work-Life Balance yaitu Work Interference with Personal Life, Personal Life Interfence with Work, Personal Life Enhancement of Work dan Work Enchancement of Personal Life. Kesimpulan yang dapat diambil pada penelitian ini bahwa work-life balance para karyawan Bank BJB dapat dikategorikan baik, dikarenakan semua dimensi yang dimiliki para karyawan menunjukkan hasil positif.
\end{abstract}

Kata Kunci : Work Life Balance, Personnel Life, Work Interfence

\begin{abstract}
This study aims to find out and analyze the Work-Life Balance of Bank BJB employees in Indramayu Branch. Important dimensions in Work-life Balance are Work Interference with Personal Life, Personal Life Interaction with Work, Personal Life Enhancement of Work and Work Enchancement of Personal Life. The research method used in this study is a qualitative-descriptive method. This study analyzes and describes the state of Work-Life Balance of BJB Branch employees in Indramayu Branch. Data obtained for this study were obtained from related party interviews and documentation studies. The results of this study indicate that Bank BJB Branch employees Indramayu has four Work-Life Balance dimensions, namely Work Interference with Personal Life, Personal Life Interaction with Work, Personal Life Enhancement of Work and Work Enhancement of Personal Life. The conclusion that can be taken in this study is that the work-life balance of BJB Bank employees can be categorized as good, because all dimensions possessed by employees show positive results.
\end{abstract}

\section{Keywords : Work Life Balance, Personnel Life, Work interfence}

\section{PENDAhUluaN}

Sumber daya manusia atau karyawan dianggap sebagai salah satu dari beberapa faktor penting dalam suatu organisasi untuk melayani peran sebagai mekanisme atau sarana bagi organisasi untuk mencapai tujuannya. Agar organisasi berhasil mencapai tujuannya, organisasi mana pun perlu memperoleh karyawan yang kompeten serta loyal dan atau berkomitmen pada organisasi. Komitmen organisasi diperlukan karena mencerminkan loyalitas, motivasi, dan inisiatif karyawan untuk melakukan upaya untuk organisasi. Work-life balance adalah situasi dimana karyawan dapat secara setara memenuhi tuntutan pekerjaan, memenuhi komitmen atau tanggung jawab keluarga mereka, dan tanggung jawab atau kebutuhan lainnya seperti aktivitas sosial.

Setiap pekerja membutuhkan keseimbangan antara kehidupan pribadi mereka dengan kehidupan kerja atau yang biasa disebut work-life balance. Hal ini menjadi penting, karena ketika seseorang hanya berfokus pada satu hal saja maka akan mengurangi 
produktivitas diri terkait kehidupan pribadi ataupun kehidupan kerja. Membagi fokus menjadi dua antara kehidupan pribadi dan kerja bukanlah hal yang mudah. Pada kenyataannya kehidupan pribadi dan perkejaan bukan dua hal yang bisa dipisahkan, karena keduanya saling berpengaruh satu sama lain.

Work-life balance berhubungan dengan kemampuan karyawan dalam menghadapi tekanan pekerjaan tanpa mengabaikan berbagai aspek kehidupan pribadi mereka. Besarnya tanggung jawab dan beban yang dirasakan oleh karyawan berbanding terbalik dengan tingkat work-life balance mereka. Semakin besar tekanan dan beban pekerjaan, semakin tinggi pula tingkat stres karyawan, dan akan semakin rendah tingkat work-life balance mereka.

Sebelum era smartphone dan internet, batas antara pekerjaan dan kehidupan pribadi dapat dilihat dengan jelas. Mungkin seseorang akan mulai bekerja ketika sudah sampai di kantor dan berhenti ketika sore hari. Namun tidak demikian dengan sekarang, lewat smartphone dan internet kita bisa berkirim email serta melakukan koordinasi kapan saja dan dimana saja. Pekerja juga bisa membuat presentasi, menulis dokumen, bahkan mengontrol server dari rumah, asalkan ada smartphone dan internet. Sedikit demi sedikit, pekerjaan pun menyusup masuk ke waktu pribadi, jam tidur, bahkan hari libur seorang pekerja.

Kebijakan jam kerja standar yang ditetapkan oleh pemerintah dapat dianggap sebagai salah satu kebijakan untuk mencegah pekerja yang bekerja terlalu keras. Namun pada prakteknya tidak semudah itu untuk menemukan keseimbangan pekerjaan dan kehidupan pribadi. Karyawan selalu dihadapkan pada target dan beban kerja yang mengakibatkan kerja lembur. Begitupun dengan industri perbankan, salah satunya adalah Bank Jabar Banten atau yang sering disingkat BJB yang merupakan bank daerah kebanggaan warga Jabar dan Banten. Belum lagi, ketika akhir bulan, di mana karyawan Bank BJB Cabang Indramayu diharuskan untuk bekerja melebihi jam operasional atau justru menggunakan hari libur untuk menyelesaikan pekerjaan. Bekerja lembur di kantor mengisolasi karyawan dari dunia luar - interaksi mereka dengan keluarga berkurang, dan tidak dapat bersosialisasi di luar lingkungan kerja. Masalah ini dapat mengakibatkan keseimbangan kehidupan kerja yang buruk dari karyawan bank. Fenomena di atas tidak lantas membuat karyawan BJB Cabang Indramayu merasa kesulitan dalam membagi waktu ataupun peran mereka. Karyawan mengatakan bahwa itu merupakan sebuah tanggung jawab yang sudah diprediksi dari awal mereka memutuskan untuk menjadi karyawan bank. Tidak adanya tuntutan yang berlebih dari keluarga juga membuat karyawan puas atas pekerjaannya.

Bank BJB Cabang Indramayu memiliki 108 karyawan yang terbagi ke dalam beberapa unit kerja dan memiliki beban kerja yang berbeda setiap unitnya. Sadar akan beban kerja karyawannya yang tidak ringan, maka Bank BJB Cabang Indramayu berusaha untuk dapat menyeimbangkan pekerjaan dengan kehidupan pribadi karyawannya. BJB Club adalah salah satu alternatif yang diberikan kepada karyawan untuk dapat menyalurkan hobi olahraga dan seni para karyawannya. Tak jarang selain untuk menjadi obat stres bagi para pegawai ini juga dapat mempererat hubungan antar karyawan. Program BJB Club disambut baik oleh para karyawan. Selain itu Bank BJB Cabang Indramayu juga rutin untuk melakukan wisata, dimana para karyawan diperbolehkan untuk mengajak anggota keluarganya.

Berdasarkan fenomena yang telah peneliti dapatkan di BJB Cabang Indramayu, maka penulis memilih judul : Analisis Worklife Balance Para Karyawan Bank BJB Cabang Indramayu.

\section{KAJIAN PUSTAKA}

\subsection{Work-Life Balance}

Fisher, Bulger \& Smith (2009) mendefnisikan "Work-life balance define it as the balance of an individual's levels of work and private life. Work and family are the most crucial domains in most people's lives, therefore, balancing these two domains in essential for the well-being of the individual." Worklife balance didefinisikan sebagai keseimbangan tingkat pekerjaan dan kehidupan pribadi seseorang. Pekerjaan dan keluarga adalah hal yang paling penting dalam kehidupan kebanyakan orang, oleh karena itu menyeimbangkan kedua hal ini sangat penting untuk kesejahteraan individu.

Hill, dkk dalam Poulose \& Sudarsan (2017: 2) mendefinisikan "work-life balance as the extent to which a person can concurrently balance the emotional, behavioural and time demands of both paid work, personal and family responsibilities." Work-life balance didefinisikan sebagai sejauh mana seseorang secara bersamaan dapat menyeimbangkan tuntutan emosional, perilaku dan waktu baik dari pekerjaan yang dibayar, tanggung jawab pribadi dan keluarga.

\subsubsection{Manfaat Work-Life Balance bagi Individu}

Melihat betapa pentingnya work-life balance bagi setiap pekerja, sudah pasti memiliki manfaat bagi individu yang menerapkan konsep ini. Menurut Stephan Kaiser et al. (2011), terdapat beberapa manfaat work-life balance bagi individu, diantaranya:

\section{Physical and Psychological Health Outcomes}

Work-life balance memberikan pengaruh untuk mengurangi gangguan fisik dan psikologis seperti penyakit, kelelahan (Bianchi et al., 2005; Peeters et al., 2005) dan depresi, serta dapat juga mengurangi ketergantungan pada alkohol dan obat-obatan.

2. Domain-Specific Satisfaction, Role Quality and Overall Satisfaction Menurut penelitian yang dilakukan Hewlett dan Luce (2006) dalam Stephan Kaiser et al. (2011) mengatakan bahwa

116 | Jurnal Akuntansi, Ekonomi dan Manajemen Bisnis | Vol. 8 No.1, July 2020, 115-126 | E-ISSN: 2548-9836 
beberapa pekerja ekstrim yang profesional mencoba mengurangi waktu kerja mereka meskipun sulit dan hasilnya memiliki waktu istirahat yang lebih puas.

Menurut Greenhaus et al. (2005) dalam Stephan Kaiser et al. (2011), mengatakan bahwa mereka yang menghabiskan waktu lebih banyak bersama keluarga memiliki kualitas kehidupan yang baik daripada mereka yang bahkan menghabiskan waktu yang sama di dua peran tersebut.

Hal ini menunjukkan bahwa sebenernya kedua peran kerja dan pribadi tersebut bisa saling memberi dampak positif satu dengan yang lain.

\section{Reduced Stress}

Persepsi konflik work-life balance selalu saja dikaitkan dengan tingkat stres seseorang. Sejumlah besar penelitian pun menunjukkan bahwa mengurangi konflik work-life balance berarti dapat menurunkan tingkat stres seseorang yang berarti dapat menghindari hasil kesehatan yang negatif.

\subsubsection{Aspek-aspek Work-Life Balance}

Work-life balance secara umum berkaitan dengan waktu kerja, fleksibilitas, kesejahteraan, keluarga, demografi, migrasi, waktu luang dan sebagainya. Work-life balance merupakan hal yang esensial karena tidak tercapainya work-life balance berakibat pada rendahnya kepuasan kerja, rendahnya kebahagiaan, work-life conflict, dan burnout pada karyawan. Beberapa ahli memberikan pandangan tentang aspek-aspek work-life balance. Menurut Hudson (2005) menyebutkan bahwa ada tiga aspek work-life balance, yaitu:

1. Keseimbangan waktu (Time balance)

Time balance merujuk pada jumlah waktu yang diberikan oleh individu baik bagi pekerjaannya maupun hal-hal diluar pekerjaan. Keseimbangan waktu yang dimiliki oleh karyawan menentukan jumlah waktu yang dialokasikan oleh karyawan pada pekerjaan maupun kehidupan pribadi mereka dengan keluarga, beragam aktivitas kantor, keluarga ataupun tempat bersosialisasi lainnya

2. Keseimbangan keterlibatan (Involvement Balance) Aspek ini berkaitan dengan jumlah atau tingkat keterlibatan secara psikologis dan komitmen suatu individu dalam pekerjaannya maupun halhal diluar pekerjaannya. Waktu yang dialokasikan dengan baik belum tentu cukup untuk menyatakan tingkat work-life balance seorang karyawan, melainkan harus didukung dengan jumlah ataupun kapasitas keterlibatan yang berkualitas di setiap kegiatan yang karyawan tersebut jalani.

3. Keseimbangan Kepuasan (Satisfaction balance)
Satisfaction balance merujuk pada tingkat kepuasan suatu individu terhadap kegiatan pekerjaannya maupun hal-hal di luar pekerjaannya. Kepuasan tersebut akan timbul dengan sendirinya apabila karyawan menganggap apa yang dilakukan selama bekerja sudah baik dalam mengakomodasi kebutuhan pekerjaan maupun keluarga. Hal ini dilihat dari kondisi yang ada pada keluarga, hubungan dengan temanteman maupun rekan kerja, serta kualitas dan kuantitas pekerjaan yang diselesaikan.

\subsubsection{Faktor-Faktor Work-Life Balance}

Ada beberapa faktor yang menyebabkan seseorang dapat memiliki work-life balance, seperti yang diungkapkan oleh Schabracq, Winnubst dan Coope (2003) yaitu:

1. Karakteristik Kepribadian

Hal ini berpengaruh terhadap kehidupan kerja dan diluar kerja. Terdapat hubungan antara tipe attachment yang diperoleh individu saat masih kecil dengan work-life balance. Individu yang memiliki secure attachment cenderung mengalami positive spillover dibandingkan individu yang memiliki insecure attachment.

2. Karakteristik Keluarga

Ini merupakan salah satu faktor penting yang bisa menentukan ada tidaknya konflik antara pekerjaan dan kehidupan pribadi seseorang.

3. Karakteristik Pekerjaan

Karakteristik ini meliputi pola kerja, beban kerja dan jumlah waktu yang digunakan untuk bekerja dan memicu adanya konflik, baik konflik dalam pekerjaan maupun konflik dalam kehidupan pribadi.

4. Sikap

Ini merupakan evaluasi terhadap berbagai aspek dalam dunia sosial, dimana dalam sikap terdapat komponen seperti pengetahuan, perasaaan dan kecenderungan untuk bertindak. Sikap dari masing-masing individu merupakan salah satu faktor yang mempengaruhi work-life balance.

\subsubsection{Dimensi Work-Life Balance}

Fisher, Bulger, dan Smith (2009) mengatakan bahwa work-life balance memiliki 4 dimensi pembentuk, yaitu :

1. WIPL (Work Interference With Personal Life) Dimensi ini mengacu pada sejauh mana pekerjaan dapat menjadi penghambat atau mengganggu kehidupan pribadi individu. Misalnya, pekerjaan dapat membuat seseorang menjadi sulit mengatur waktu untuk kehidupan pribadinya.

2. PLIW (Personal Life Interference With Work) Dimensi ini mengacu pada sejauh mana kehidupan pribadi individu mengganggu 
kehidupan pekerjaannya. Misalnya, apabila individu memiiliki masalah didalam kehidupan pribadinya, hal ini dapat mengganggu kinerja individu pada saat bekerja.

3. PLEW (Personal Life Enhancement Of Work) Dimensi ini mengacu pada sejauh mana kehidupan pribadi seseorang dapat meningkatkan performa individu dalam bekerja. Misalnya, ketika individu merasa senang karena kehidupan pribadinya yang menyenangkan maka hal ini tentu saja dapat membuat suasana hati individu pada saat bekerja menjadi menyenangkan.

4. WEPL (Work Enhancement Of Personal Life) Dimensi ini mengacu pada sejauh mana pekerjaan dapat meningkatkan kualitas kehidupan pribadi individu. Misalnya keterampilan yang diperoleh individu pada saat bekerja, hal ini memungkinkan individu untuk memanfaatkan keterampilan tersebut dalam kehidupan seharihari.

\section{METODELOGI PENELITIAN}

\subsection{Jenis Penelitian}

Jenis penelitian yang digunakan pada penelitian ini adalah metode kualitatif. Metode penelitian kualitatif disebut juga metode naturalistik karena penelitiannya dilakukan pada kondisi yang alamiah.; disebut juga sebagai metode etnographi, karena pada awalnya metode ini lebih banyak digunakan untuk bidang antropologi budaya; disebut juga metode kualitatif, karena data yang terkumpul dan analisisnya bersifat kualitatif.

\subsection{Desain Penelitian}

Dalam penelitian ini, peneliti menggunakan metode penelitian deskriptif. Menurut Bungin (2010: 68), penelitian deskriptif adalah penelitian yang betujuan untuk menggambarkan, meringkaskan berbagai kondisi, berbagai situasi atau berbagai fenomena realitas sosial yang ada di masyarakat yang menjadi objek penelitian, dan berupaya menarik realitas itu ke permukaan sebagai suatu ciri, karakter, sifat, model, tanda atau gambaran tentang kondisi, situasi atapun fenomena tertentu.

\subsection{Sumber data}

Sumber data primer penelitian ini yaitu informan dalam hal ini adalah para karyawan Bank BJB Cabang Indramayu. Sedangkan sumber data sekunder penulis dapatkan dari buku-buku, artikel ataupun jurnal tentang work-life balance yang dapat menunjang kegiatan penelitian.

\subsection{Operasional Konsep}

Menurut Sekaran (2003: 87) "a variable is anything that can take on differing or varying values". Pada penelitian ini, penulis menetapkan satu variabel yaitu work-life balance. Peneliti menggunakan teori dari Fisher, Bulger dan Smith sebagai dasar melakukan penelitian

\subsection{Teknik Pengumpulan Data}

Dalam penelitian ini penulis menggunakan teknik komunikasi langsung. Adapun teknik pengumpulan data yang digunakan oleh peneliti jika dilihat dari segi cara, diantaranya:

1. Wawancara tak berstruktur (unstuctured interview) Wawancara tidak terstruktur adalah wawancara yang bebas dimana peneliti tidak menggunakan pedoman wawancara yang telah tersusun secara sistematis dan lengkap untuk pengumpulan datanya. Pedoman wawancara yang digunakan hanya berupa garis-garis besar permasalahan yang akan ditanyakan. (Sugiyono, 2013:74)

2. Dokumen

Dokumen merupakan catatan peristiwa yang sudah berlalu. Dokumen bisa berbentuk tulisan, gambar, atau karya-karya monumental dari seseorang.

\subsection{Teknik Analisis Data}

Wiratna (2015: 34) mengatakan bahwa analisis data dilakukan selama pengumpulan data di lapangan dan setelah semua data terkumpul dengan teknik analisis model interaktif. Analisis data berlangsung secara bersama-sama dengan proses pengumpulan data dengan alur tahapan sebagai berikut:

1. Reduksi data

Data yang diperoleh kemudian ditulis dalam bentuk laporan atau data yang terperinci. Laporan yang disusun berdasarkan data yang diperoleh direduksi, dirangkum, dipilih hal-hal pokok dan difokuskan pada hal-hal yang penting. Data kemudian dipilih berdasarkan satuan konsep, tema dan kategori tertentu yang nantinya akan memberikan gambaran yang lebih tajam tentang hasil pengamatan juga mempermudah peneliti untuk mencari kembali data sebagai tambahan atas data sebelumnya yang diperoleh.

2. Penyajian data

Data yang diperoleh dikategorikan menurut pokok permasalahan dan dibuat dalam bentuk matriks sehingga memudahkan peneliti untuk melihat pola-pola hubungan satu data dengan yang lainnya.

3. Penyimpulan dan Verifikasi

Data yang sudah direduksi dan disajikan secara sistematis akan disimpulkan sementara.

4. Kesimpulan Akhir

Kesimpulan akhir diperoleh berdasarkan kesimpulan sementara yang telah diverifikasi. Kesimpulan final ini diharapkan dapat didapat setelah pengumpulan data selesai. 


\subsection{Pengujian Kredibilitas Data}

Menurut Sugiyono (2013: 122-125), pengujian kredibilitas data penelitian dapat dilakukan dengan cara:

1. Meningkatkan Ketekunan

Meningkatkan ketekunan, dengan cara tersebut maka kepastian data dan urutan peristiwa akan dapat direkam secara pasti dan sistematis. Sebagai bekal peneliti untuk meningkatkan ketekunan adalah dengan cara membaca berbagai referensi buku maupun hasil penelitian atau dokumentasidokumentasi yang terkait dengan temuan yang diteliti.

2. Triangulasi

Pengujian kredibilitas data penelitian ini menggunakan triangulasi sumber. Triangulasi sumber dilakukan untuk menguji kredibilitas data yang dilakukan dengan cara mengecek data yang telah diperoleh melalui beberapa sumber. Data yang telah dianalisis oleh peneliti sehingga menghasilkan suatu kesimpulan yang selanjutnya dimintakan kesepakatan (member check) dengan sumber tersebut. Penulis melakukan teknik pengumpulan data yaitu dengan wawancara mendalam dan dokumentasi kepada beberapa sumber tersebut.

\section{HASIL PENELITIAN}

\subsection{Gambaran Umum Informan Penelitian}

Informan utama dalam penelitian ini adalah 6 orang karyawan Bank BJB Cabang Indramayu yang terdiri dari berbagai unit kerja. Pemilihan informan ini dibantu oleh karyawan bagian Sekretariat dan Umum yang mengurus masalah kepegawaian di Bank BJB Cabang Indramayu. Selain informan utama, peneliti juga berusaha untuk mencari informan tambahan yang berasal dari keluarga karyawan agar memperluas perspektif penelitian ini. Namun, dari 6 orang informan yang sudah diwawancara sebelumnya, peneliti hanya berhasil mewawancarai 1 orang anggota keluarga dikarenakan informan lain keberatan untuk diwawancara. Berikut peneliti tampilkan informan penelitian pada tabel dibawah ini:

Tabel 1. Informan Utama Penelitian

\begin{tabular}{|c|l|l|}
\hline No. & \multicolumn{1}{|c|}{ Informan } & \multicolumn{1}{|c|}{ Posisi } \\
\hline 1. & $\begin{array}{l}\text { Prima Kurnia } \\
\text { (Informan 1) }\end{array}$ & $\begin{array}{l}\text { Account Officer } \\
\text { Komersial (Unit } \\
\text { Kerja Bisnis) }\end{array}$ \\
\hline 2. & $\begin{array}{l}\text { Ricky } \\
\text { Rachmat } \\
\text { (Informan) }\end{array}$ & $\begin{array}{l}\text { Credit Risk (Unit } \\
\text { Kerja Bisnis) }\end{array}$ \\
\hline
\end{tabular}

\begin{tabular}{|c|l|lr|}
\hline 3. & $\begin{array}{l}\text { Reghy } \\
\text { Safaregny } \\
\text { (Informan 3) }\end{array}$ & $\begin{array}{l}\text { Customer Srvice } \\
\text { (Unit Kerja } \\
\text { Operasional) }\end{array}$ \\
\hline 4. & $\begin{array}{l}\text { Andrian } \\
\text { (Informan 4) }\end{array}$ & $\begin{array}{l}\text { Teller (Unit Kerja } \\
\text { Operasional) }\end{array}$ \\
\hline 5. & $\begin{array}{l}\text { Farasulton } \\
\text { (Informan 5) }\end{array}$ & $\begin{array}{l}\text { Staff Teknologi } \\
\text { Informasi ( Unit } \\
\text { Kerja Supporting) }\end{array}$ \\
\hline 6. & $\begin{array}{l}\text { Sari } \\
\text { (Informan 6) }\end{array}$ & $\begin{array}{llr}\text { Sekretariat } \\
\text { mum }\end{array}$ \\
\hline 7. & Ibu Elly & $\begin{array}{l}\text { Unit } \\
\text { erja }\end{array}$ \\
\hline
\end{tabular}

Penelitian ini dilakukan dengan mendatangi kantor Bank BJB Cabang Indramayu untuk melakukan wawancara dengan para karyawan dari berbagai unit kerja. Wawancara dilakukan di sore hari ketika kegiatan operasional sudah tidak terlalu sibuk, sehingga tidak mengganggu pekerjaan para karyawan. Peneliti menyerahkan kepada Sekretariat \& Umum untuk memilihkan karyawan yang dapat dijadikan informan. Pada hari pertama dan kedua wawancara, peneliti selalu diberikan 2 informan sekaligus untuk diwawancara. Situasi ini menguntungkan dari segi waktu dan ketersediaan informasi, karena ketika proses wawancara dilakukan informan bisa saling melempar argumen masing-masing. Selanjutnya, untuk informan yang berasal dari keluarga karyawan, peneliti hanya mampu mewawancarai lewat sambungan telefon dikarenakan waktu dan jarak yang jauh. Berdasarkan hasil wawancara dari beberapa informan dan studi dokumentasi diharapkan semakin berkurangnya subjektivitas dalam pengumpulan data penelitian. Data dan informasi yang diberikan oleh para informan digunakan untuk membantu peneliti dalam mengolah dan menganalisis data yang berhubungan dengan work-life balance yang ada di Bank BJB Cabang Indramayu.

\subsection{Work-life balance para karyawan Bank BJB Cabang Indramayu}

Bank BJB adalah bank BUMD milik Pemerintah Provinsi Jawa Barat dan Banten yang berkantor pusat di Bandung. Bank ini didirikan pada tanggal 20 Mei 1961 dengan bentuk perseroan terbatas (PT), kemudian dalam perkembangannya berubah status menjadi Badan Usaha Milik Daerah (BUMD). Saat ini Bank BJB memiliki 63 Kantor Cabang, 311 Kantor Cabang Pembantu, 330 Kantor 
Kas, 1202 ATM BJB, 103 Payment Point, 4 Kantor Wilayah, dan 473 Waroeng BJB. Salah satu kantor cabang yang dimiliki Bank BJB berada di Indramayu dengan jumlah karyawan sebanyak 108 orang yang terdiri dari berbagai jabatan dan unit kerja.

Istilah work-life balance memang masih asing di telinga karyawan Bank BJB Cabang Indramayu, namun hal ini bukan berarti membuat Bank BJB Cabang Indramayu tidak memperhatikan hal tersebut. Salah satu cara yang dilakukan oleh Bank BJB Cabang Indramayu adalah dengan mengadakan program BJB Club Futsal, zumba, bersepeda bahkan hiking adalah beberapa jenis olahraga yang dihadirkan di BJB Club guna mengakomodir hobi para karyawannya. Program ini mendapat sambutan baik dari para karyawan yang antusias untuk menikmati fasilitas yang diberikan oleh Bank BJB. Selain itu, Bank BJB pun setiap tahunnya rutin mengadakan rekreasi bersama yang memperbolehkan karyawan untuk mengajak anggota keluarganya. Programprogram yang dilakukan dapat membuat karyawan semakin akrab dengan rekan kerja yang lain dan juga mereka memiliki wadah untuk menyalurkan hobi serta menghabiskan waktu dengan keluarga.

Dari sisi karyawan pun, para karyawan Bank BJB Cabang Indramayu mengatakan bahwa mereka dapat membagi perannya antara pekerjaan, keluarga dan kehidupan pribadinya dengan baik di tengah kesibukan sebagai karyawan bank. Para informan mengatakan bahwa tidak sulit untuk membagi perannya, karena mereka masih dapat mengerjakan pekerjaan dengan baik, lalu mereka masih bisa menghabiskan waktu dengan keluarga bahkan mereka pun masih memiliki waktu untuk dapat mengerjakan hobi atau sekedar untuk bertemu dengan teman-teman mereka di luar kantor. Hal ini diperkuat oleh teori Anil Kumar and Sandeep Krishnan (2005) dalam Sonia Mehrotra and K. Nirmala Prasad (2011: 325) yang mengatakan bahwa work-life balance diartikan sebagai tingkat kepuasaan dan keterlibatan antara peran seseorang dalam kehidupannya.

Peneliti akan memberikan analisis mengenai work-life balance para karyawan Bank BJB Cabang Indramayu dengan dimensi yang sudah ada pada teori work-life balance menurut Fisher, Bulger dan Smith (2009). Dimensi tersebut adalah, Work Interference with Personal Life (WIPL), Personal Life Interfence with Work (PLIW), Personal Life Enhancement of Work (PLEW) dan Work Enchancement of Personal Life (WEPL).

\subsection{Work Interference With Personal LIfe}

Dimensi work interference with personal life mengacu pada sejauh mana pekerjaan dapat menjadi penghambat atau mengganggu kehidupan pribadi individu (Fisher, Bulger dan Smith, 2009). Pekerjaan yang mengganggu atau menghambat kehidupan pribadi seorang karyawan berpotensi untuk menimbulkan konflik, baik dalam pekerjaan ataupun kehidupan pribadi seseorang. Dimensi work interference with personal life merupakan dimensi pertama dari teori work- life balance. Pada dimensi ini terdapat beberapa indikator yaitu; jumlah jam kerja, waktu bertemu keluarga dan waktu untuk kehidupan pribadi.

Semua indikator dalam dimensi ini mengacu pada jumlah waktu keterlibatan karyawan baik dalam pekerjaan ataupun dalam kehidupan pribadi. Namun, seperti yang telah dikatakan oleh Hudson (2005) bahwa:

"Waktu yang dialokasikan dengan baik belum tentu cukup untuk menyatakan tingkat work-life balance seorang karyawan, melainkan harus didukung dengan jumlah ataupun kapasitas keterlibatan yang berkualitas di setiap kegiatan yang karyawan tersebut jalani."

Tingkat keseimbangan memang tidak bisa hanya diukur dengan waktu saja, tetapi bagaimana seorang karyawan dapat memaksimalkan keterlibatannya dalam waktu yang telah mereka alokasikan untuk setiap aspek dalam kehidupan. Jika keseimbangan hanya diukur dari waktu semata maka "keseimbangan" tersebut tidak akan pernah tercapai, karena akan selalu ada ketimpangan terhadap pembagian waktu tersebut.

Bank BJB Cabang Indramayu menerapkan SOP jam kerja lima hari dalam seminggu, dari jam 07.30 sampai dengan jam 16.30. Karyawan mengatakan bahwa jam kerja tersebut sebenarnya cukup untuk menyelesaikan pekerjaan sesuai dengan jobdesc mereka. Namun memang ada beberapa hal yang dapat menyebabkan karyawan bekerja melebihi jam operasional ataupun ada pekerjaan yang tidak dapat terselesaikan dalam sehari. Staff dari unit kerja bisnis mengatakan bahwa, hal ini disebabkan karena pekerjaan mereka berkaitan dengan berbagai pihak seperti kreditur dan atasan mereka. Ketika kreditur atau nasabah tersebut tidak dapat melengkapi persyaratan, maka pekerjaan tersebut tidak dapat diproses sampai selesai di hari itu juga. Pekerjaan mereka pun tidak berhenti sampai disitu karena mereka harus mendapatkan persetujuan dari manager dan pimpinan cabang. Namun, di Bank BJB terdapat SLA atau Standar Level Approvment yang di dalamnya terdapat jangka waktu maksimal karyawan untuk menyelesaikan pekerjaannya. Memang, unit kerja bisnis merupakan unit kerja yang bisa dikatakan beban kerjanya paling berat karena mereka dihadapkan pada target yang harus dicapai. Selain itu, untuk bagian frontliner yang pekerjaanya dihadapkan pada jumlah nasabah yang banyak setiap harinya menuntut mereka untuk dapat melaksanakan pekerjaan dengan cepat. Namun, memang ada di beberapa waktu yang mengharuskan mereka lembur bahkan di hari libur seperti hari Sabtu dan Minggu untuk melakukan pencatatan dan perbaikan data.

Secara keseluruhan, informan mengatakan bahwa mereka dapat menyelesaikan tugasnya sesuai dengan 
waktu yang telah ditentukan. Sekretaris \& Umum merupakan salah satu bagian yang bekerja pada back office, dimana infroman mengatakan bahwa untuk yang bekerja dibagian back office itu terkadang pekerjaan dating tidak terduga. Back office bisa saja tidak memiliki pekerjaan yang banyak di pagi hingga menjelang siang, namun setelah itu bisa menjadi sangat sibuk. Dalam situasi seperti ini dibutuhkan kemampuan untuk menentukan prioritas atas pekerjaan, seperti pekerjaan mana yang harus diselesaikan terlebih dahulu.

Karyawan tidak keberatan untuk melakukan penambahan waktu kerja karena itu sudah merupakan konsekuensi yang harus diambil sebagai seorang pegawai bank. Lembur pun sudah bukan hal yang asing bagi para karyawan Bank BJB Cabang Indramayu, namun memang tidak dilakukan setiap saat. Bukan cuma-cuma karayawan melakukan lembur, pihak Bank BJB Cabang Indramayu juga memberi uang lembur sebagai bentuk apresiasi.

Waktu bertemu keluarga merupakan indikator dari work interference with personal life yang kedua. Dari hasil wawanacara yang dilakukan kepada informan, jam kerja di Bank BJB Cabang Indramayu tidak mempengaruhi jumlah waktu untuk bertemu keluarga. Para karyawan masih dapat meluangkan waktunya untuk dapat berkumpul atau sekedar makan bersama keluarga karena memang rata-rata informan yang diwawancara merupakan orang asli Indramayu sehingga mereka dapat bertemu dengan keluarga mereka setiap harinya. Seperti yang dikatakan oleh Hill, dkk dalam Poulose \& Sudarsan (2017: 2) bahwa "Work-life balance didefinisikan sebagai sejauh mana seseorang secara bersamaan dapat menyeimbangkan tuntutan emosional, perilaku dan waktu baik dari pekerjaan yang dibayar, tanggung jawab pribadi dan keluarga."

Para karyawan selalu berusaha untuk dapat mengalokasikan waktunya dengan keluarga di tengah kesibukan sebagai seorang pegawai bank, karena keluarga merupakan orang terdekat mereka untuk berbagi keluh kesah. Namun ada salah satu informan bagian teller yang harus tinggal berpisah dari keluarga dan memutuskan untuk kost di daerah sekitar Bank BJB, hal ini membuat waktu untuk bertemu keluarga hanya bisa didapatkan hari Sabtu dan Minggu saja.

Menurut teller Bank BJB Indramayu: "Kalau saya kan biarpun orang Indramayu tapi saya ngekos. Liburkan sabtu mingu, itu harus dimaksimalin, jadi dari hari Jumat tuh udah dipikirin apa nih yang harus dilakuin, karena memang saya kerja dari rumah berangkat senin, senin sampe jumat di Indramayu full (Kost) ya memang jauh dari orang tua. Otomatis waktu yang bisa dipake cuma sabtu minggu aja, kadang minggu juga udah mulai kepikiran gitu untuk ngantor.”

Pernyataan ini coba peneliti konfimasi kepada keluarga informan dalam hal ini adalah ibu dari informan. Dari hasil wawancara didapati bahwa memang benar Teller tersebut selalu berusaha untuk bisa membagi waktu antara pekerjaan dengan kehidupan pribadinya. Ia selalu mengusahakan untuk pulang setiap akhir pekan untuk bisa menghabiskan waktu bersama keluarga di rumah bahkan ketika Hari Sabtu harus dihadapkan pada lembur sekalipun. Keluarga tidak pernah memaksa ataupun menuntut karyawan tersebut untuk selalu pulang setiap akhir pekan karena khawatir anggota keluarganya kelelahan. Dihadapkan pada pekerjaan setiap hari membuat seseorang perlu untuk mencari "pelarian" atas pekerjaannya. Bentuk pelarian ini bisa dengan mengerjakan hobi ataupun sekedar berkumpul dengan teman-teman. Ini juga yang dilakukan karyawan Bank BJB ketika mereka sedang tidak bekerja. Seperti menyadari kebutuhan karyawannya, Bank BJB memiliki program bernama BJB Club yang memberikan fasilitas kepada karyawan untuk menyalurkan hobinya terutama dalam bidang olahraga. Program ini dilakukan di sela-sela pekerjaan, seperti olahraga futsal pada malam hari dan karyawan akan menyempatkan untuk dapat mengikutinya. Selain itu, biasanya setiap Hari Minggu juga karyawan beramairamai untuk bersepeda. Program ini diterima secara positif oleh karyawan karena dirasa selain dapat menyalurkan hobi mereka pun bisa bercengkrama dengan teman-teman kantor dan mengurangi kejenuhan dalam bekerja. Atmosfir yang coba dibangun Bank BJB Cabang Indramayu dapat meminimalkan konflik dan meningkatkan kepuasan di antara karyawan. Hal ini senada dengan hasil penelitian yang dilakukan Nadeem dan Abbas (2009), dimana mereka menyarankan agar karyawan memiliki kepuasan kerja yang baik perlu manajemen yang mendukung agar menjadi obat untuk meminimalkan konflik dan meningkatkan kepuasan antar karyawan.

Dari hasil wawancara didapati bahwa selain memanfaatkan program BJB Club, karyawan memiliki cara lain untuk dapat menikmati waktu pribadinya. Salah satu caranya adalah bertemu dengan teman-teman selain rekan kerja di kantor. Interaksi terus menerus dengan rekan kerja di kantor memberikan kejenuhan bagi karyawan sehingga mereka butuh untuk bertemu dengan temanteman selain rekan kerja. Beberapa karyawan masih dapat menyempatkan bertemu dengan temanteman untuk sekedar mengobrol setelah pulang kerja.

Karyawan Bank BJB merasa tidak kesulitan dalam membagi peran mereka antara pekerjaan dengan waktu bersama keluarga dan kehidupan pribadi, hal ini karena karyawan menyadari pentingnya membagi peran antara ketiganya. Hal ini selaras dengan apa yang dikatakan oleh Fisher, Bulger dan Smith (2009) bahwa work-life balance merupakan keseimbangan tingkat pekerjaan dan kehidupan pribadi seseorang. 


\subsection{Personal Life Interfrence with Work (PLIW)}

Fisher, Bulger dan Smith (2009) mengatakan bahwa Personal Life Interfrenece with Work adalah dimensi yang mengacu pada sejauh mana kehidupan pribadi individu mengganggu kehidupan pekerjaannya. Batas antara kehidupan pribadi dengan pekerjaan bisa sangat sulit terpisahkan, namun setiap karyawan harus dapat membagi batas tersebut agar dapat mengurangi tingkat stress baik dalam kehidupan pekerjaan ataupun kehidupan pribadi.

Dari hasil wawancara yang dilakukan, didapati bahwa kehidupan pribadi karyawan Bank BJB tidak mengganggu pekerjaannya karena justru kehidupan pribadi karyawan memberikan dampak positif. Dukungan sangat diberikan oleh keluarga dan temanteman kepada karyawan Bank BJB Cabang Indramayu. Karyawan mengatakan bahwa keluarga memahami kesibukan mereka sebagai karyawan bank. Bagi karyawan yang sudah berkeluarga, mereka mengatakan bahwa tidak ada hambatan yang diberikan oleh keluarga terkait pekerjaan, karena karyawan menikah setelah mereka menjadi pegawai Bank BJB Cabang Indramayu yang membuat keluarga dapat memahami itu. Untuk karyawan yang belum menikah pun, perannya sebagai seorang anak tidak menghambat pekerjaan sehari-hari Setiap perusahaan memberikan cuti tahunan yang merupakan hak karyawan dan cuti ini memang harus diambil oleh setiap karyawan, karena ketika seorang karyawan tidak memanfaatkan waktu cuti ini maka akan menimbulkan kecurigaan terhadap karyawan tersebut. Biasanya pengambilan cuti berkaitan dengan peran seorang karyawan terhadap kehidupannya di luar pekerjaan, dimana karyawan ingin menghabiskan waktu lebih dengan keluarga seperti liburan, pulang ke kampung halaman atau bahkan sekedar untuk istirahat di rumah.

Tanggung jawab yang berbeda-beda dijalani oleh setiap karyawan di Bank BJB Cabang Indramayu, baik dalam pekerjaan ataupun tanggung jawab di rumah. Beberapa informan yang diwawancara, tiga diantaranya menjalani peran sebagai seorang kepala keluarga dan tiga orang lainnya masih belum memiliki beban untuk keluarga mereka sendiri. Walaupun peran yang dijalankan berbeda tetapi, para karyawan ini kompak mengatakan bahwa keluarga mereka tidak pernah membatasi atau menghalangi pekerjaan mereka selama ini. Distraksi dari keluarga pasti selalu ada, seperti kabar orang tua sakit dan lain sebagainya namun sebisa mungkin para karyawan dapat memfokuskan diri untuk menyelesaikan pekerjaannya tanpa mengesampingkan peran dalam keluarga. Seperti yang dikatakan oleh salah satu informan dari bagian Teller yang merasa fokusnya terpecah ketika mendapatkan kabar orang tua sakit, namun sebisa mungkin untuk dapat menyelesaikan pekerjaan dengan baik dan rutin untuk menanyakan kabar orang tua di rumah. Hal ini pun dibenarkan oleh orang tua dari informan yang mengatakan bahwa anggota keluarga selalu memberikan perhatian kepada orang tua dengan selalu menanyakan kabar di tengah-tengah kesibukan bekerja.

Jam kerja yang terkadang tidak bisa diprediksi serta pekerjaan yang banyak memang membutuhkan dukungan dari keluarga, sebagai orang terdekat dari para karyawan. Dukungan ini sangat dirasakan oleh para karyawan Bank BJB Cabang Indramayu. Dukungan tersebut bisa dalam bentuk pemahaman ataupun pengertian tentang kesibukan para karyawan. Memang ada beberapa karyawan yang mengatakan bahwa di awal mereka menjadi pegawai bank, keluarga sempat memberikan protes karena anggota keluarganya masih bekerja sampai malam hari, namun hal ini tidak berlangsung lama karena keluarga pun pada akhirnya memaklumi peran yang dijalani karyawan tersebut. Untuk karyawan yang sudah berkeluarga pun tidak pernah ada protes yang berarti dari kelurga mereka karena karyawan menikah setelah bekerja di Bank BJB sehingga keluarga dapat memahami. Dukungan yang diberikan membantu karyawan untuk mefokuskan diri dalam menyelesaikan tugas-tugas di kantor dan membagi peran dengan baik.

Ketepatan waktu dalam menyelesaikan sebuah tugas merupakan kewajiban setiap karyawan di perusahaan manapun, sama halnya dengan para karyawan Bank BJB Cabang Indramayu. Karyawan selalu berusaha menyelesaikan pekerjaannya dengan tepat waktu, walaupun memang ada beberapa pekerjaan yang tidak terselesaikan dalam satu hari kerja. Hal ini terjadi bukan berasal dari gangguan yang diberikan keluarga, tetapi memang berasal dari aspekaspek dalam pekerjaan mereka. Dikatakan oleh para informan bahwa yang biasanya membuat pekerjaan tidak selesai tepat waktu adalah persyaratanpersyaratan yang diajukan oleh nasabah tidak lengkap, kemudian ketersediaan manager atau pimpinan cabang sebagai orang yang berhak memberi tanda tangan beberapa dokumen dan hal-hal lain yang berasal dari pekerjaan.

\subsection{Personal Life Enhancemenr of Work Life (PLEW)}

Personal Life Enhancement of Work Life merupakan dimensi work-life balance yang ketiga dan dimensi ini mengacu pada sejauh mana kehidupan pribadi seseorang dapat meningkatkan performa individu dalam bekerja. Kehidupan pribadi dapat meningkatkan performa dengan adanya dukungan dari orang terdekat seperti keluarga ataupun lingkungan sosial para karyawan. Indikator dari dimensi ini ada tiga yaitu, suasana kerja, hubungan dengan rekan kerja dan kehidupan sosial di luar pekerjaan.

Suasana kerja bisa disebut juga sebagai lingkungan kerja. Lingkungan kerja adalah segala sesuatu yang ada di sekitar para pekerja yang dapat mempengaruhi dirinya dalam menjalankan tugas-tugas yang dibebankan. Suatu lingkungan kerja dapat 
dikatakan baik apabila lingkungan kerja tersebut sehat, nyaman, aman dan menyenangkan bagi karyawan. Hal ini yang nampak pada Bank BJB Cabang Indramayu, peneliti memperhatikan lingkungan fisik Bank BJB terlihat sangat bersih dan tertata rapi bahkan dari mulai parkiran, bagian operasional seperti teller dan CS serta ruangan-ruangan lainnya pun tertata rapi dengan pendingin ruangan dan pengharum ruangan. Ini diperkuat juga dengan hasil wawancara kepada karyawan yang mengatakan bahwa mereka nyaman dengan lingkungan kerja tersebut.

Selain lingkungan kerja fisik seperti diatas, ada juga lingkungan kerja non fisik. Menurut Sedarnayanti (2009:31) lingkungan kerja non fisik adalah semua keadaan yang terjadi yang berkaitan dengan hubungan kerja, baik dengan atasan, sesama rekan kerja ataupun bawahan. Ketika peneliti menanyakan tentang hubungan kerja kepada karyawan mereka semua menjawab hubungan kerja dengan team sangat baik. Setiap orang menyadari perannya masing-masing dan menyadari juga peran rekan kerjanya sehingga para karyawan bisa saling meng-cover satu sama lain. Setiap karyawan juga bekerja dengan profesional bahwa tidak ada urusan keluarga yang dibawa kedalam pekerjaan sehingga suasana kerja tetap nyaman. Tetapi tidak dipungkiri bahwa gesekan kerja itu selalu ada seperti yang dikatakan oleh salah satu informan:

"Kalau suasana kerja ya di Bank BJB itu sendiri kan antara Bisnis, Operasional dan Supporting kan ngga bisa lepas. Itu kan keterkaitan semuanya, jadi suasana disini kondusif cuma yang namanya tempat kerja pasti selalu ada gesekan-gesekan tapi itu tidak mempengaruhi kinerja" Pada Bank BJB Cabang Indramayu memang terdapat tiga unit kerja yaitu Bisnis, Operasional dan Supporting, dimana ketiga unit kerja ini saling bekerja sama dalam melakukan pekerjaan. Hubungan sosial dengan manusia pasti akan selalu mengalami gesekan, terlebih dalam hal pekerjaan. Gesekan tersebut biasanya disebabkan karena komunikasi antar karyawan, namun seperti yang sudah dijelaskan oleh informan bahwa gesekan tersebut tidak mempengaruhi pekerjaan mereka.

Ada fenomena yang menarik terlebih dari bagian frontliner dimana karyawan bekerja dengan lingkungan yang selalu ramai dengan nasabah dan karyawan pun dituntut untuk dapat bekerja dengan cepat. Tidak jarang, hal ini menyebabkan protes yang langsung dilayangkan kepada para karyawan di bagian frontliner. Kejadian ini sedikit banyaknya pasti membuat mood karyawan terganggung, terlebih bagi salah satu infoman bagian Customer Service yang memang merasa dirinya sedikit emosional. Namun, ada satu prinsip yang diterapkan oleh karyawan bagian frontliner bahwa "nasabah adalah raja" jadi apapun yang dilakukan oleh nasabah pasti selalu benar dan tugas karyawan adalah memberikan pelayanan yang terbaik. Informan lain dari bagian frontliner pun mengatakan hal yang sama. Mendapat protes dan bentakan dari nasabah sudah menjadi santapan sehari-hari, tetapi ada juga memang nasabah yang memperlakukan karyawan dengan baik dan mengerti pekerjaan mereka. Nasabah seperti ini yang bisa mengembalikan mood menjadi lebih baik. Ditambah memang team work yang terjalani di Bank BJB baik sehingga karyawan tetap dapat bekerja dengan profesional apapun keadaannya.

Di luar pekerjaan, kehidupan sosial karyawan juga memberikan dampak positif kepada pribadi karyawan. Karyawan selalu meluangkan waktu untuk bisa bertemu dengan teman-teman, misalnya sekedar makan bersama ataupun berbagi keluh kesah tentang pekerjaan. Setiap setelah bertemu dengan temanteman, karyawan merasa seperti mendapatkan energi lebih untuk bekerja keeosokan harinya. Seperti yang dikatakan oleh salah satu informan dari Customer Service:

"Sangat sangat, karena kita ini kan dalam lingkungan kerja temennya itu-itu aja bisa dibilang bosen sih. Ya alhamdulillahnya saya dari kecil di Indramayu jadi temen-temen saya pun disini semua, kalau udah bosen sama kerjaan terus ketemu temen tuh enak gitu berpengaruh untuk pekerjaan besok harinya. Kaya ngecharge energi."

Dukungan selain bisa didapatkan dari keluarga, juga bisa didapatkan dari lingkungan pertemanan yang sehat dan saling mendukung. Berdasarkan hasil wawancara yang sudah dilakukan, karyawan yang belum berkeluarga memang lebih sering menghabiskan waktu dengan teman-teman. Hal ini disebabkan karena para karyawan yang belum berkeluarga ini tidak memiliki beban tambahan untuk membagi waktunya dengan keluarga mereka, berbeda dengan karyawan yang sudah berkeluarga.

Schabracq, Winnubst dan Coope (2003) mengatakan bahwa salah satu faktor work-life balance pada diri seseorang adalah karakteristik keluarga, karakteristik ini bisa berpengaruh terhadap keberadaan konflik pada pekerjaan ataupun kehidupan pribadi karyawan. Diberikan keluarga yang selalu mendukung pekerjaan para anggota keluarga merupakan sebuah hal yang patut disyukuri setiap karyawan, yang artinya konflik peranpun akan semakin kecil untuk dapat terjadi.

Dukungan bisa didapatkan dari lingkungan yang positif, seperti keluarga dan juga teman. Selain itu, lingkungan yang diciptakan di dalam pekerjaan juga sangat mempengaruhi mood karyawan dalam menyelesaikan pekerjaannya. Karyawan harus pintar untuk menjaga mood pribadi dalam berbagai situasi, hal ini bisa membantu dirinya untuk dapat menyelesaikan pekerjaan dengan baik ataupun tidak mengganggu mood rekan kerja yang lain. Ketika semua karyawan dapat saling menghargai, suasana kerja akan semakin nyaman. 


\subsection{Work Enhancement of Personal Life (WEPL)}

Dimensi yang terakhir ini memberikan gambaran sejauh mana pekerjaan dapat meningkatkan kualitas kehidupan pribadi seorang karyawan. Tidak hanya kehidupan pribadi yang dapat memberikan dampak baik bagi pekerjaan, tetapi pekerjaan pun dapat memberikan dampak positif bagi kehidupan pribadi setiap karyawan. Dampak positif yang dapat dirasakan karyawan salah satunya adalah kemampuan yang mereka dapatkan di kantor bisa diaplikasikan pada kehidupan di luar kantor. Hal ini menjadi value lebih bagi karyawan bahwa apa yang dikerjakan di kantor dapat membantunya di luar.

Dari hasil wawancara yang dilakukan, karyawan mengatakan bahwa banyak kemampuan yang didapat selama bekerja sebagai karyawan di Bank BJB Cabang Indramayu. Kemampuankemampuan yang sudah didapat selain untuk menunjang pekerjaan karyawan dalam menjalankan pekerjaannya, itu juga dapat membantu kehidupan mereka di luar kantor.

Kemampuan yang didapatkan para karyawan selama bekerja baik melalui pelatihan yang diadakan ataupun yang karyawan dapatkan selama mengerjakan pekerjaannya, kemampuan-kemampuan ini yang dianggap oleh para karyawan dapat membantu kehidupan mereka di luar kantor. Contohnya karyawan bagian sekretariat dan umum yang merasa kemampuan public relation yang dimiliki sangat membantunya untuk dapat menempatkan diri dengan orang yang berbeda- beda karena ia terbiasa untuk bertemu dengan orang-orang dari berbagai jabatan selama bekerja. Bank BJB Cabang Indramayu memiliki program bernama BJB Pengembangankanku. Program ini merupakan program pelatihan yang diberikan untuk para karyawannya, pembahasan dalam pelatihan bisa disesuaikan dengan kebutuhan karyawan. Pengadaan program tersebut sejalan dengan salah satu budaya Bank BJB yaitu karyawan yang memiliki keinginan kuat untuk mengembangkan diri. Pengembangan diri yang dilakukan tidak hanya pada saat pelatihan tetapi juga karyawan dapat mengembangkan ketika sedang melaksanakan pekerjaan sehari-hari.

Para karyawan Bank BJB cabang Indramayu selalu berusaha untuk terus mengembangkan diri dalam pekerjaannya, sehingga ketika para karyawan merasa kesulitan dan butuh masukan tentang pekerjaan maka mereka akan bertanya kepada rekan kerja ataupun pada karyawan lain yang lebih senior. Namun memang sharing ini hanya dilakukan sebatas lingkup pekerjaan saja. Di Bank BJB Cabang Indramayu belum ada program counseling yang ditujukan untuk berbagi masalah pribadi karyawan. Dari hasil wawancara yang dilakukan, sejauh ini jika karyawan ingin berbagi cerita tentang kehidupan pribadi hanya kepada rekan kerja yang dianggap dekat saja.
Berdasarkan penjelasan dari keempat dimensi diatas, terlihat bahwa work-life balance para karyawan Bank BJB Cabang Indramayu dapat dikatakan baik karena semua dimensi yang telah disebutkan memberikan hasil positif baik bagi kehidupan pekerjaan ataupun kehidupan pribadi karyawan. Dimensi pertama yaitu Work Interference with Personal Life yang memberikan hasil bahwa pekerjaan tidak menganggu kehidupan pribadi karyawan. Dimensi kedua, Personal Life Interfence with Work memberikan hasil bahwa kehidupan pribadi karyawan juga tidak menganggu pekerjaan sebagai pegawai bank. Ketiga Personal Life Enhancement of Work, memberikan hasil bahwa kehidupan pribadi pekerja dapat memberikan dampak positif kepada performa karyawan serta yang terakhir Work Enchancement of Personal Life, bahwa pada dimensi ini karyawan Bank BJB mendapatkan beberapa kemampuan yang dapat digunakan untuk membantu kehidupan mereka diluar pekerjaan.

\section{KESIMPULAN DAN SARAN \\ 5.1. Kesimpulan}

Pembahasan penelitian telah dilakukan oleh peneliti mengenai analisis work-life balance para karyawan Bank BJB Cabang Indramayu. Dari hasil wawancara yang dilakukan kepada karyawan dan anggota keluarga karyawan Bank BJB Cabang Indramayu terkait work-life balance, maka dapat diambil kesimpulan sebagai berikut:

1. Dimensi pertama yaitu Work-Interference with Personal Life. Karyawan Bank BJB Cabang Indramayu memiliki beban kerja yang banyak dan jam kerja yang panjang tidak membuat peran dalam kehidupan pribadinya menjadi bermasalah. Waktu untuk bertemu keluarga, bekerja dan untuk kehidupan pribadi dapat dijalankan dengan baik sesuai dengan peran masing-masing.

2. Dimensi kedua yaitu Personal Life Interference with Work, bahwa pada dimensi ini tidak ada permasalahan pada kehidupan pribadi karyawan yang dapat menganggu pekerjaan terkait tanggung jawab di kantor serta ketepatan waktu dalam menyelesaikan tugas. Masalah dalam penyelesaian pekerjaan selalu disebabkan karena birokrasi yang ada di Bank BJB Cabang Indramayu.

3. Dimensi ketiga yaitu Personal Life Enhancement of Work Life yang meliputi suasana kerja, hubungan dengan rekan kerja dan kehidupan sosial di luar pekerjaan. Ketiga indikator tersebut menunjukkan hasil yang positif dan berdampak baik pada semangat kerja karyawan dalam menyelesaikan pekerjaan.

4. Dimensi terakhir yaitu Work Enhancement of Personal Life yang menjabarkan sejauh mana keterampilan yang didapat karyawan dapat 
berguna bagi kehidupan di luar pekerjaan. Beberapa keterampilan berhasil didapatkan oleh karyawan selama bekerja yang juga dapat memberikan dampak positif terkait peran mereka di luar pekerjaan. Kemampuan- kemampuan tersebut didapatkan baik melalui pelatihan yang diberikan ataupun mengalir begitu saja seiring dengan waktu mereka bekerja selama di Bank BJB Cabang Indramayu

\subsection{Saran}

Berdasarkan penelitian yang telah dilakukan di lapangan, maka peneliti memberikan beberapa saran baik kepada karyawan maupun kepada Bank BJB Cabang Indramayu yang berkaitan dengan work-life balance, sebagai berikut:

1. Meningkatkan awareness terkait work-life balance kepada karyawan, bisa dengan cara memasukkannya pada nilai-nilai perusahaan yang kemudian dapat diterapkan ke dalam programprogram yang menunjang work-life balance karyawan. Misalnya dengan mengadakan program konseling yang berguna untuk menggali informasi terkait kehidupan pribadi karyawan. Harapannya dengan informasi tersebut dapat memberikan gambaran jika nantinya terdapat indikasi penurunan produktivitas karyawan yang dipengaruhi oleh masalah pada kehidupan pribadinya.

2. Bank BJB Cabang Indramayu dapat meningkatkan wawasan karyawan melalui motivation learning terkait penguasaan manajemen diri agar karyawan semakin baik lagi dalam membagi proporsi perannya terkait pekerjaan maupun kehidupan pribadinya. Hal ini dapat semakin mengembangkan soft skills karyawan dalam hal tanggung jawab atas pekerjaan mereka dan semakin pandai untuk menempatkan diri baik dalam pekerjaan maupun kehidupan pribadi karyawan.

3. Karyawan Bank BJB Cabang Indramayu memang sudah memiliki work-life balance yang baik. Hal ini perlu dipertahankan agar kedua peran tersebut tetap dapat berjalan dengan baik dengan cara selalu menjaga komunikasi dengan keluarga terkait agenda pekerjaan dan agenda lain diluar pekerjaan serta dapat juga membuat todo-list yang akan dilakukan dalam kurun waktu tertentu, misalnya dalam seminggu atau sebulan sekali.

\section{REFERENSI}

A. Agarwal, Sucheta and Usha Lenka. 2015. Study of Work Life Balance of Women EntrepreneursReview and Research Agenda. International and Commercial Training, volume 47, no. 7, p 356362.
B. Bianchi, S. M., Casper, L. M., \& King, R. B. (2005). Complex connections: A multidisciplinary look at work, family, health, and well-being research. In S. M. Bianchi, L. M.

Casper, \& R. B. King (Eds.), Work, family, health and well-being (pp. 1-17).

Mahwah, NJ: Lawrence Erlbaum Associates.

C. Bungin, Burhan. 2010. Penelitian Kualitatif: Komunikasi, Ekonomi, Kebijakan Publik, Dan Ilmu Sosial Lainnya. Jakarta: Kencana.

D. Creswell, J. W. 2016. Research Design Pendekatan Metode Kualitatif, Kuantitatif dan Campuran. Yogyakarta: Pustaka Pelajar.

E. Dev, S. Sathya and S. John Mano Kaj. 2017. Work-Life Balance Effect on Work Related Factor in Nationalized Banks. Shanlax International Journal of Management, volume 4, no. 4.

F. Fisher, G. G., et al. 2009. Beyond Work and Family A Measure of Work/Nonwork Interference and Enhancement. Journal of Occupational Helath Psychology, Volume 14, no. 4, p 441-456

G. Hewlett, S. A., \& Luce, C. B. (2006). Extreme jobs: The dangerous allure of the 70-hour workweek. Harvard Business Review, 84(12), 4959.

H. Hudson. 2005. The Case for Work/Life Balance: Closing the Gap Between Poliy and Pratice. New York: Hudson Higland Group, Inc.

I. Kaiser, Stephan, et al. 2011. Creating Balance? International Perspectives on the Work-Life Integration on Professionals. London: Springer Heidelberg Dordrecht.

J. Mehrotra, S and K. Nirmala Prasad. 2011. Quality of Work Life as a Mediator to Work Life Imbalance of Professional Women. International Journal of Arts \& Sciences, volume 4, no.12, p 324-325.

K. Nadeem, M.S and Abbas. 2009. The Impact of Work-Life Conflict on Job Satisfaction of Employees in Pakistan. International Journal of Business and Management, volume 4, no. 5, p 6383

L. Peeters, Maria C. W.,Montgomery, Anthony J.,Bakker, Arnold B.,Schaufeli, Wilmar B.Peeters, M. C. W., Montgomery, A. J., Bakker, A. B., \& Schaufeli, W. B. (2005). Balancing Work and Home: How Job and Home Demands Are 
Related to Burnout. International Journal of Stress Management, 12(1), 43-61. https://doi.org/10.1037/1072-5245.12.1.43

M. Poulose, Shobitha and Sudarson N. 2017. WorkLife Balance: A Conceptual Review. International Journal of Advances in Management and Economics, Volume 3, No. 2, p. 01-17

N. Schabracq, Marc J, et al. 2003. The Handbook of Work \& Health. England: John Wisley \& Sons Ltd.

O. Sedarnayanti. 2009. Pengembangan Kepribadian Karyawan. Bandung: Mandar Maju

P. Sekaran, Uma. 2003. Research Methods for Business: A Skill Building Approach $4^{\text {th }}$ Edition. New York: John Willey and Sons, Inc.
Q. Sugiyono. 2013. Metode Penelitian Administrasi dilengkapi dengan Metode $R \& D$. Bandung: Alfabeta.

R. 2016. Metode Penelitian Kuantitatif, Kualitatif, dan $R \& D$. Bandung: Alfabeta. 